\title{
Observations of the ultrastructure of infected kidney stones
}

\author{
R. J. C. MCLEAN§, J. C. NICKEL*, T. J. BEVERIDGE and J. W. COSTERTON $\dagger$
}

Department of Microbiology, University of Guelph, Guelph, Ontario, Canada N1G 2W1, "Department of Urology, Queen's University, Kingston, Ontario, Canada K7L 3N6, and tDepartment of Biology, University of Calgary, Calgary, Alberta, Canada T2N 1N4

\begin{abstract}
Summary. Struvite stones are formed as the result of urinary tract infection by ureaseproducing bacteria. Ultrastructural examination of calculi removed from a patient revealed bacteria incorporated throughout the stone matrix. Exopolysaccharide stained by ruthenium red was associated with most of the bacteria, but it represented only a small portion of the organic matrix in the stone. Localised deposits of calcium and phosphorus, components of carbonate-apatite, and magnesium, a struvite component, were detected in close proximity to the cells. Histochemical examinations revealed that several of the gram-negative bacteria within the stone matrix possessed high levels of urease activity. We propose that bacterial slime production, intimately involved in the initiation of stone matrix deposition, is less prominent in mature stones because of the increased incorporation of host-derived mucoproteins and mucopolysaccharides.
\end{abstract}

\section{Introduction}

Putrefying urine has been associated with the occurrence of kidney stones since the time of Hippocrates (Blath, 1977). The $10-20 \%$ of the patients with kidney stones that develop these struvite $\left(\mathrm{NH}_{4} \mathrm{MgPO}_{4} \cdot 6 \mathrm{H}_{2} \mathrm{O}\right)$ and carbonate-apatite $\left(\mathrm{Ca}_{10}\left(\mathrm{PO}_{4}\right)_{6} \mathrm{CO}_{3}\right)$ calculi commonly have an alkaline urine due to the presence of ureolytic bacteria in the urinary tract (Griffith, 1978; Fowler, 1984).

Urinary calculi caused by infection consist of two major components-an inorganic mineral component, and an organic matrix (Vermeulen et al., 1965; Vermeulen and Lyon, 1968; Griffith, 1978). In-vitro experiments have established the role of bacterial urease in the production of the struvite and carbonate-apatite mineral components of these stones (Griffith et al., 1976; Hedelin et al., 1985). Ammonia, produced by the bacterial hydrolysis of urea, raises urine $\mathrm{pH}$ and causes precipitation of $\mathrm{Mg}^{2+}, \mathrm{Ca}^{2+}, \mathrm{CO}_{3}{ }^{2-}$, and $\mathrm{PO}_{4}{ }^{3-}$ as struvite and carbonate-apatite (McLean et al., 1988). A third mineral component of these stones, newberyite $\left(\mathrm{MgHPO}_{4} \cdot 3 \mathrm{H}_{2} \mathrm{O}\right)$ has recently been described (Uebelhart et al., 1984). The origin of the organic

Received 18 Dec. 1986; revised version accepted 12 Jan. 1988.

$\S$ Present address to which correspondence should be sent: $\mathrm{Dr}$ R. J. C. McLean, Departments of Urology and Microbiology \& Immunology, Queen's University, Kingston, Ontario, Canada K7L 3N6. matrix components is less clear. Chemical analysis of the stone matrix reveals the presence of mucoproteins, mucopolysaccharides, and glycosaminoglycans (Boyce and Garvey, 1956; Wickham, 1975, 1982).

Two theories of matrix deposition have been proposed. The first states that matrix deposition occurs solely as a consequence of struvite crystallisation (Vermeulen et al., 1965; Vermeulen and Lyon, 1968). However, Boyce and Garvey (1956) proposed that matrix deposition was a prerequisite for stone growth. As crystal-free regions or "matrix" stones are quite often found at the periphery of struvite stones (Wickham, 1975, 1982), it is probable that matrix formation precedes crystallisation.

In previous in-vitro (McLean et al., 1985b) and animal model experiments (Nickel et al., 1987) of struvite stone production, we proposed that bacterial exopolysaccharide production plays an initial important role in establishing the organic stone matrix. In this report we confirm our hypothesis of infection stone aetiology with in-vivo observations of bacterial slime and urease activity within a stone taken from a patient.

\section{Materials and methods}

\section{Patient history and isolation of calculi}

Struvite and carbonate-apatite calculi were obtained from a nephrostomy tube in an elderly male patient. This 
patient had a long history of recurrent struvite stone production and changing catheter flora in spite of continuous antibiotic therapy. Urease-producing strains of gram-negative Providencia rettgeri, and gram-positive Staphylococcus aureus and Streptococcus group D were isolated. Examination by polarised light microscopy (Prien and Frondel, 1947) revealed that these calculi contained approximately equal amounts of struvite and carbonate-apatite.

\section{Transmission electronmicroscopy (TEM)}

Stone samples were processed for conventional transmission electronmicroscopy, as follows. The organic crystal-containing material which lined the luminal surface of the nephrostomy tube was removed with a sterile scalpel blade, fixed in glutaraldehyde $2 \%$ in $1 \% \mathrm{w} /$ v N-2-hydroxyethylpiperazine- $\mathrm{N}$-2-ethanesulfonic acid (HEPES) buffer, $\mathrm{pH} 7 \cdot 0$, and mounted in agar. Samples were then washed in HEPES buffer, stained with $\mathrm{OsO}_{4}$ $2 \% \mathrm{w} / \mathrm{v}$ in HEPES buffer, washed again in HEPES buffer, and dehydrated in a graded acetone series. Infiltration, embedding and polymerisation with Spurr (1969) resin were performed according to the method of Marrie and Costerton (1984). Thin sections were mounted on copper grids, stained with uranyl acetate and lead citrate, and examined with a Hitachi H-600 TEM at an accelerating voltage of $50 \mathrm{kV}$.

\section{Analytical electronmicroscopy}

Specimen preparation for analytical electronmicroscopy was similar to that for conventional electronmicroscopy except that $\mathrm{OsO}_{4}$ was not used as a fixative and thin sections were examined unstained with a Philips model 400T scanning transmission electronmicroscope with an energy dispersive X-ray analysis (EDX) analytical attachment. During specimen examination, the microscope was operated in the transmission mode with an electron beam current of $80 \mu \mathrm{A}$ at an accelerating voltage of $100 \mathrm{kV}$. The electron beam spot size used during TEMEDX elemental analysis gave an effective resolution of $100 \mathrm{~nm}$.

\section{Histochemical urease localisation}

The buffer used during histochemical urease localisation was HEPES buffer $0.85 \% \mathrm{w} / \mathrm{v}, \mathrm{pH} 7.0$ (McLean et $a l ., 1985 a$ ). Specimens to be examined for urease activity were washed for $1 \mathrm{~h}$ at room temperature in HEPES buffer, to remove traces of urine and ammonia. The specimens were then split into "reaction" and "substrate control" treatments. Urease was localised histochemically by incubating the "reaction" specimens in a trapping solution containing $5 \mathrm{~mm}$ sodium tetraphenylboron, $1 \mathrm{mM}$ EDTA and $100 \mathrm{mM}$ urea dissolved in HEPES buffer, for $4 \mathrm{~h}$ at room temperature. During this treatment, ammonia, produced by the enzymic hydrolysis of urea, was precipitated with the sodium tetraphenylboron trapping reagent. After incubation, the samples were washed in HEPES buffer, and stained with $\mathrm{AgNO}_{3} 2 \%$ w/v dissolved in HEPES (McLean et al., 1986). Samples were then embedded in agar and processed for TEM as described by McLean et al. (1986). "Substrate control" samples, which were used to monitor chemical contamination during urease localisation, were treated in a similar fashion except that the sodium tetraphenylboron trapping solution lacked urea.

\section{Results and discussion}

TEM of conventionally processed material from infective stones (fig. 1) revealed that both gramnegative and gram-positive bacteria were present. Most observed bacteria possessed ruthenium redstaining glycocalyces. Additional matrix material, probably composed of urinary mucoproteins and mucopolysaccharides, was also seen. Although the three bacterial cultures isolated from these stones were all ureolytic, reaction product deposition due to urease activity was seen only in several highly ureolytic gram-negative bacteria, presumed to be Prov. rettgeri (fig. 2). Transmission electronmicroscopy coupled with energy dispersive analysis of $\mathrm{X}$ rays (TEM-EDX) on unstained stone samples, revealed localised deposits of $\mathrm{Ca}, \mathrm{P}$ (presumably as $\mathrm{PO}_{4}$ ), and $\mathrm{Mg}$ in the vicinity of bacterial cells (fig. 3). The elemental constituents of $\mathrm{CO}_{3}{ }^{2-}$ or $\mathrm{NH}_{4}{ }^{+}$ cannot be resolved by this technique.

Infective kidney stones are interesting ecological phenomena; the bacteria responsible for their pathogenesis exhibit a commensal or symbiotic relationship with their human host when present in other regions of the body (McLean et al., 1988) such as the skin (Pillsbury and Rebell, 1952) or the gastrointestinal tract (Hespell and Smith, 1983). Urea, which enters the gastrointestinal tract by diffusion from the blood (Cheng and Wallace, 1979), is hydrolysed by urease-producing bacteria. Ammonia, resulting from this hydrolysis or from the deamination of amino acids, represents the major source of nitrogen for gastrointestinal bacteria which assimilate it into microbial protein. This microbial protein, some of which was originally derived from urea, can be used as a secondary protein source for the human host (Hespell and Smith, 1983; Leng and Nolan, 1984). In contrast to the gastrointestinal tract, the upper urinary tract (i.e., bladder and kidneys) is considered to be sterile (Kunin, 1979). The lack of an autochthonous microflora in the urinary tract probably enhances the pathogenicity of any ureolytic bacteria present, because excess ammonia generated by urease activity cannot be removed by microbial assimilation (McLean, 1986; McLean et al., 1988). 


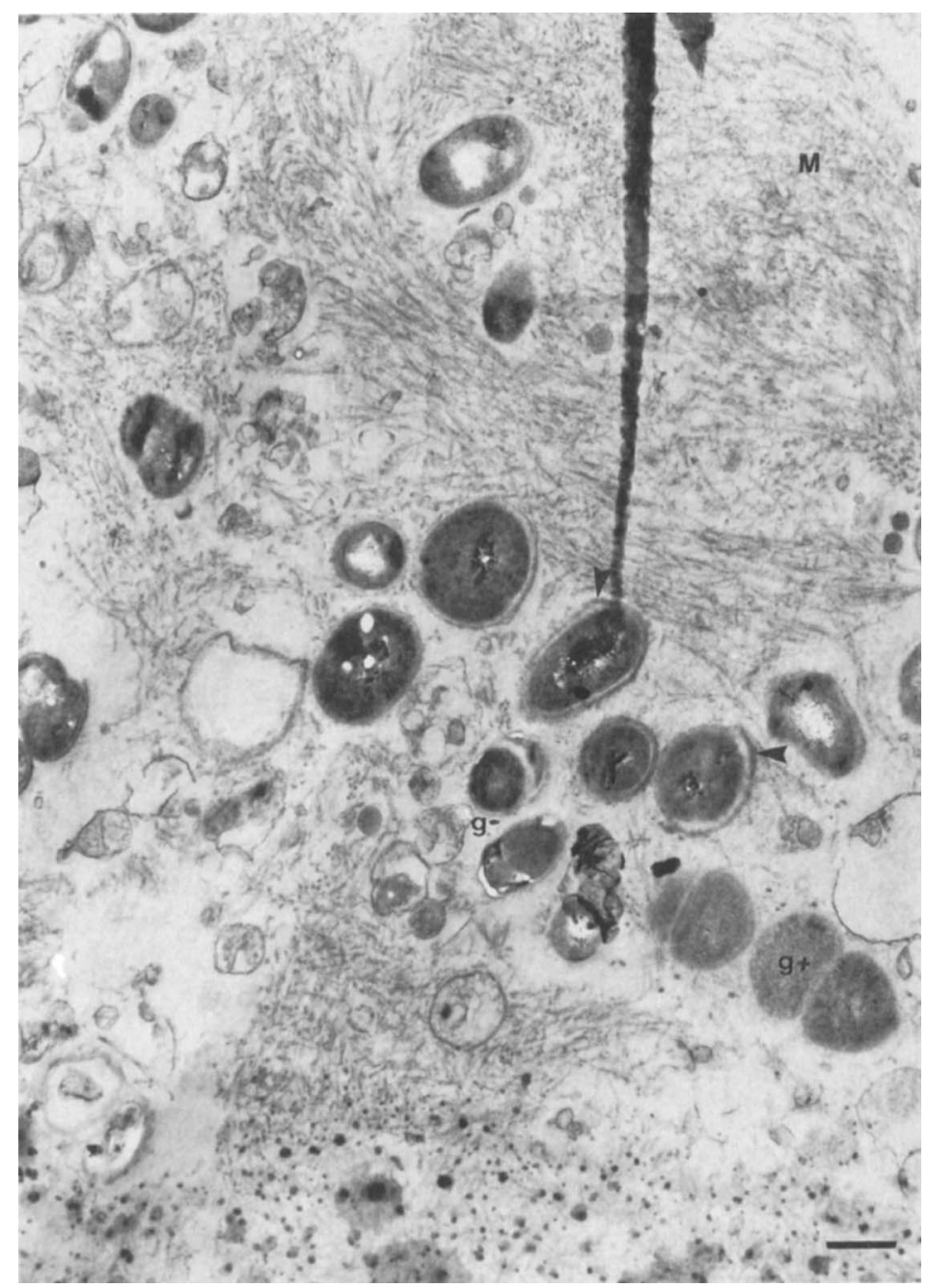

Fig. 1. TEM of a stone sample taken from a patient with a chronic history of struvite stone production. Microbiological analysis of this stone revealed a mixed infection of $P$. rettgeri, $S$. aureus, and Streptococcus sp. Note the presence of gram-positive $(\mathrm{g}+)$ and gram-negative $(\mathrm{g}-$ ) bacteria, some of which are surrounded by ruthenium red-staining glycocalyx (arrows). Matrix material (M), probably composed of urinary mucoproteins and mucopolysaccharides, is quite evident. Bar, in this and all micrographs, represents $0.4 \mu \mathrm{m}$.

We have recently shown that struvite and carbonate-apatite crystals formed in vitro as a result of bacterial urease activity in artificial urine, do not become encased in slime-like material if bacterial exopolymers are physically excluded by a dialysis membrane (Clapham et al., unpublished observations). Such loose, sand-like crystals could be easily voided with the urine in the absence of a cementing organic matrix. Thus, it would appear that bacterial slime production is involved in the initial formation of the stone organic matrix components.

TEM of conventionally prepared stone material (fig. 1) revealed that ruthenium red-staining bacte- rial exopolysaccharides constitute a relatively minor component of the organic matrix of mature infective stones. This finding agrees with biochemical analyses of the organic matrix components of these calculi (Boyce and Garvey, 1956; Wickham, 1975, 1982; Nishio et al., 1985). Therefore, we conclude that bacterial exopolysaccharide production, intimately involved in the initiation of stone matrix deposition, is less prominent in mature stones because of the increased incorporation of host-derived mucoproteins and mucopolysaccharides (McLean et al., 1985b).

The condition of the urinary tract also influences 


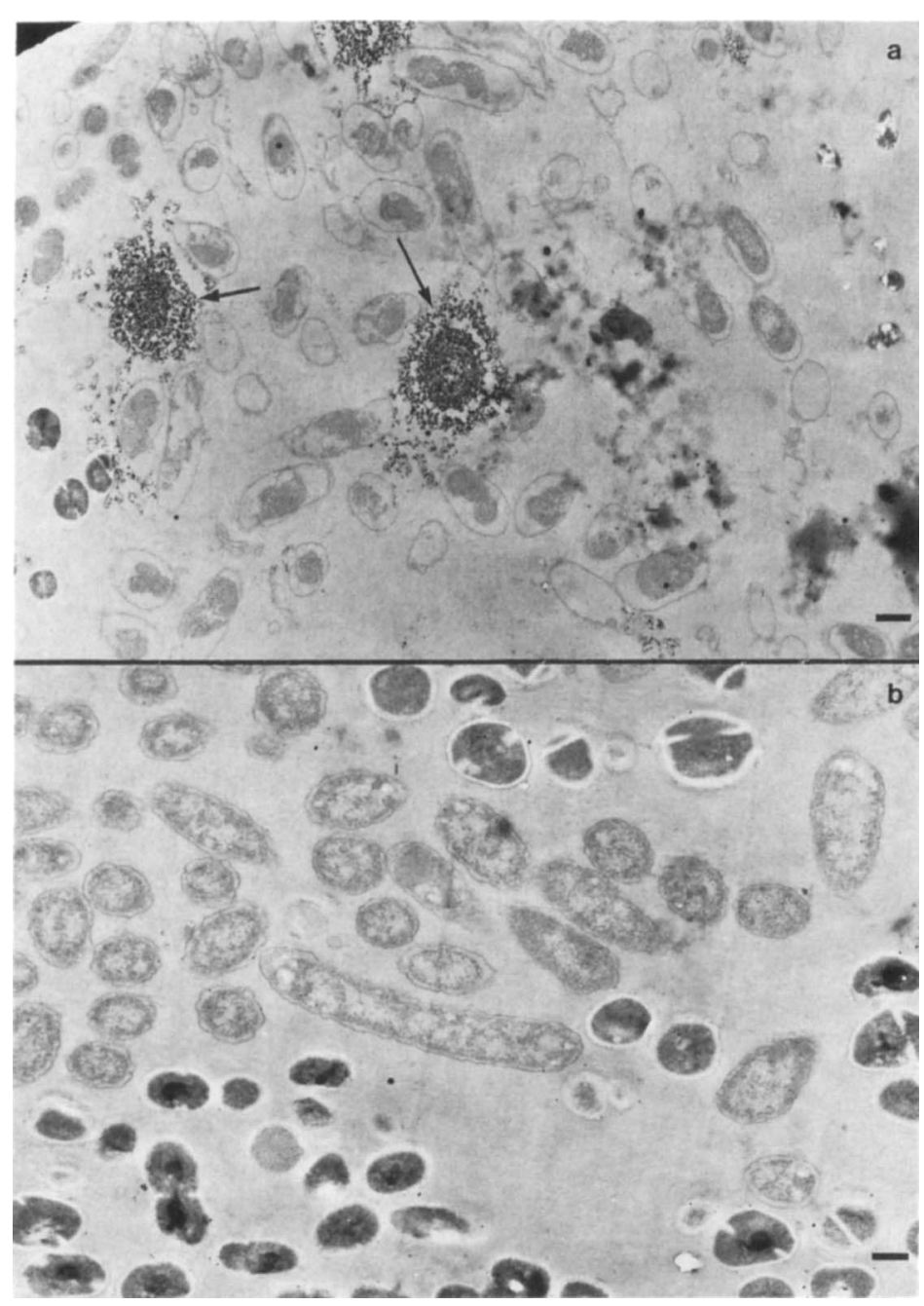

Fig. 2. Stone sample stained for urease activity (McLean et al., 1985a, 1986); large deposits of urease reaction product are shown in a few of the $P$. rettgeri cells (fig. $2 \mathrm{a}$; arrows). No reaction product was seen in the gram-positive cocci. Note the absence of reaction product in the substrate control preparation (fig. $2 \mathrm{~b}$ ).

stone development. In a recently completed animalmodel study (Nickel et al., 1987), we have shown that disruption of the urinary immune system by the presence of scar tissue in the bladder, or of a foreign object, enhances bacterial colonisation and resultant stone formation.

We propose the following aetiological process for infective kidney stone formation (outlined in fig. 4): invading ureolytic pathogens ascend the urinary tract and colonise epithelial tissue and inert surfaces as slime-enclosed microcolonies; exopolysaccharide production by these bacteria facilitates adhesion of these pathogens to surfaces, protects the organisms from urinary defence mechanisms, antibiotics and urease inhibitors, and binds and nucleates the growth of struvite and carbonate-apatite crystals that result from bacterial urease activity. Continued growth of these encrusted bacterial microcolonies into mature calculi is characterised by continued bacterial growth, urease activity by some or all the organisms present, and an increasing incorporation of urinary organic components into the stone matrix. This mechanism of stone formation would account for the well-documented presence of bacteria within the stones and the persistence of infection (Rocha and Santos, 1969; Nickel et al., 1985).

We thank J. Downey, R. Harris and R. Humphrey for technical assistance. R.J.C.M. was supported by a Career 


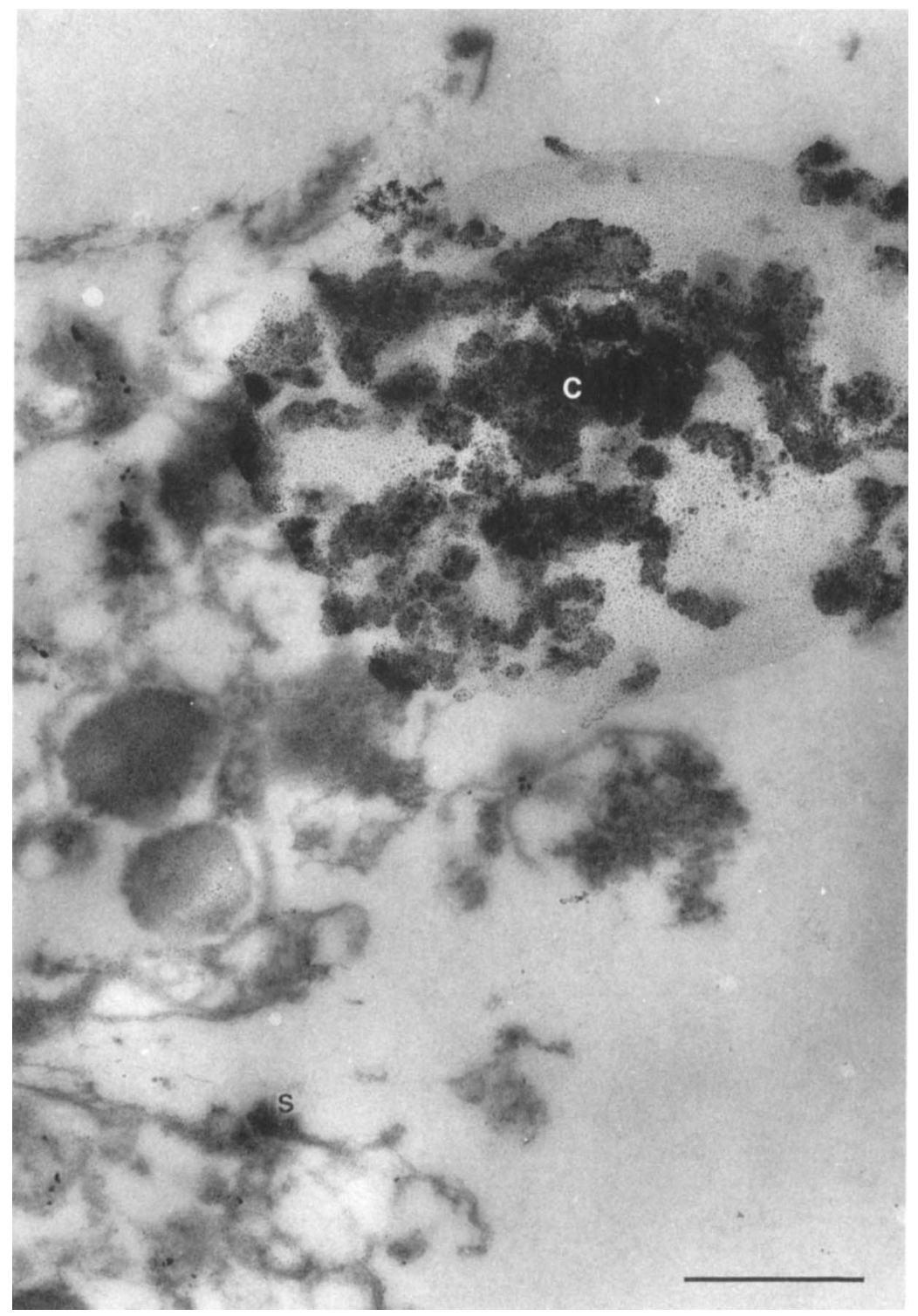

Fig. 3. Examination of an unstained stone specimen by TEM-EDX shows the majority of $\mathrm{Mg}, \mathrm{Ca}$ and $\mathrm{P}$ mineral components to be localised in electron-dense crystalline regions often found in association with bacterial cells. One such region (S) contained the struvite component, $\mathrm{Mg}$. Carbonate-apatite components $\mathrm{Ca}$ and $\mathrm{P}$ were found in a different region (C).

Scientist Fellowship from the Ontario Ministery of Health. This work was supported by the Kidney Foundation of Canada and the Alberta Heritage Foundation for Medical Research. Analytical electronmicroscopy was performed at the Guelph Regional
STEM facility, which is funded by the Natural Sciences and Engineering Research Council of Canada, and the Department of Microbiology, University of Guelph. 

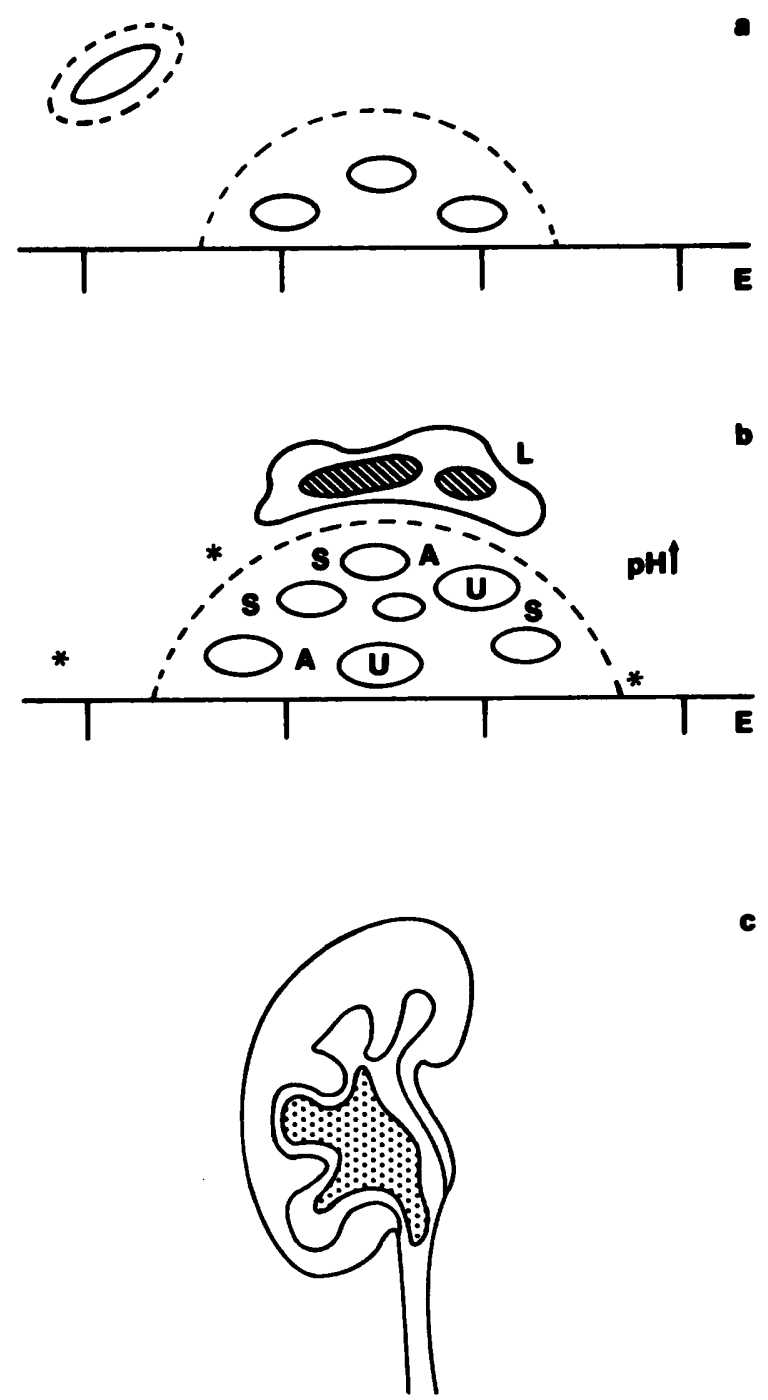

c

Fig. 4. Schematic representation of infective urinary stone pathogenesis. Infective kidney stones arise when urinary epithelial cells (E) are colonised by glycocalyx-secreting pathogens which form microcolonies (fig. 4a). Urease activity (U) by some of these pathogens (fig. 4b) raises urine pH, resulting in a precipitation of struvite (S) and apatite (A) crystals. The glycocalyx (outlined by ---) traps these crystals and other components such as mucoproteins present in the urine. The resulting organic matrix protects the pathogens from antibiotics $\left(^{*}\right)$ and host-mediated immune responses such as lymphocytes (L). Growth of these encrusted microcolonies into mature stones is characterised by continued bacterial growth, urease activity and crystal deposition, and an increasing incorporation of urinary mucoproteins into the stone matrix. The mature stone (fig. 4c) resembles an enlarged, mineralised, bacterial microcolony (Reprinted with permission from McLean et al., 1988).

\section{REFERENCES}

Blath R A 1977 Hippocrates (460-377 BC). Investigative Urology 15: 183

Boyce W H, Garvey F K 1956 The amount and nature of the organic matrix in urinary calculi: a review. Journal of Urology 76: 213-227.

Cheng K-J, Wallace R J 1979 The mechanism of passage of endogenous urea through the rumen wall and the role of ureolytic epithelial bacteria in the urea flux. British Journal of Nutrition 42 : 553-557.
Fowler J E 1984 Bacteriology of branched renal calculi and accompanying urinary tract infection. Journal of Urology 131 : 213-215.

Griffith D P 1978 Struvite stones. Kidney International 13: 372382.

Griffith D P, Musher D M, Itin C 1976 Urease-the primary cause of infection-induced urinary stones. Investigative Urology 13: 346-350.

Hedelin H, Grenabo L, Pettersson S 1985 Urease-induced crystallization in synthetic urine. Journal of Urology 133: 529-532. 
Hespell R B, Smith C J 1983 Utilization of nitrogen sources by gastrointestinal bacteria. In: Hentges D J (ed) Human intestinal microflora in health and disease. Academic Press, New York, pp 167-187.

Kunin C M 1979 Detection, prevention, and management of urinary tract infections, 3rd edn. Lea and Febiger, Philadelphia.

Leng, R A, Nolan J V 1984 Nitrogen metabolism in the rumen. Journal of Dairy Science 67: 1072-1089.

Marrie T J, Costerton J W 1984 Scanning and transmission electron microscopy of in situ bacterial colonization of intravenous and intraarterial catheters. Journal of Clinical Microbiology 19: 687-693.

McLean R J C 1986 The role of ureolytic bacteria in infectious urinary stone production. PhD thesis, University of Calgary, Alberta, Canada.

McLean R J C, Cheng K-J, Gould W J, Costerton J W $1985 a$ Cytochemical localization of urease in a rumen Staphylococcus $\mathrm{sp}$. by electron microscopy. Applied and Environmental Microbiology 49: 253-255.

McLean R J C, Cheng K-J, Gould W D, Nickel J C, Costerton J W 1986 Histochemical and biochemical urease localization in the periplasm and outer membrane of two Proteus mirabilis strains. Canadian Journal of Microbiology 32: 772778.

McLean R J C, Nickel J C, Cheng K-J, Costerton J W 1988 The ecology and pathogenicity of urease-producing bacteria in the urinary tract. CRC Critical Reviews in Microbiology, 16: $37-79$.

McLean R J C, Nickel J C, Noakes V C, Costerton J W $1985 b$ An in-vitro ultrastructural study of infectious kidney stone genesis. Infection and Immunity 49: 805-811.

Nickel J C, Emtage J, Costerton J W 1985 Ultrastructural microbial ecology of infection-induced urinary stones. Journal of Urology 133: 622-627.
Nickel J C, Olson M E, McLean R J C, Grant S K, Costerton J W 1987 An ecological study of infected urinary stone genesis in an animal model. British Journal of Urology 59: 21-30.

Nishio S et al. 1985 Matrix glycosaminoglycan in urinary stones. Journal of Urology 134: 503-505.

Pillsbury D M, Rebell G 1952 The bacterial flora of the skin. Factors influencing growth of resident and transient flora. Journal of Investigative Dermatology 18: 173-186.

Prien E L, Frondel C 1947 Studies in urolithiasis: I. The composition of urinary calculi. Journal of Urology 57: 949994.

Rocha H, Santos L C S 1969 Relapse of urinary tract infection in the presence of urinary tract calculi: the role of bacteria within the calculi. Journal of Medical Microbiology 2: 372 376.

Spurr A 1969 A low viscosity epoxy resin embedding medium for electron microscopy. Journal of Ultrastructure Research 26: $31-43$.

Uebelhart D, Wisard M, Véry J M 1984 Calcul coralliforme et infection urinaire à répétition: un cas de lithiase de newberyite $\left(\mathrm{MgHPO}_{4} \cdot 3 \mathrm{H}_{2} \mathrm{O}\right)$. Schweizerische Medizinische Wochenschrift 114: 1689-1694.

Vermeulen C W, Lyon E S 1968 Mechanisms of genesis and growth of calculi. American Journal of Medicine 45: 684692.

Vermeulen C W, Lyon E S, Fried F A 1965 On the nature of the stone forming process. Journal of Urology 94: 176-186.

Wickham J E A 1975 Matrix and the infective renal calculus. British Journal of Urology 47: 727-732.

Wickham J E A 1982 The matrix of renal calculi. In: Chisholm G D, Williams D I (eds) Scientific foundations of urology. William Heinemann Medical Books Ltd., London, pp 323329. 